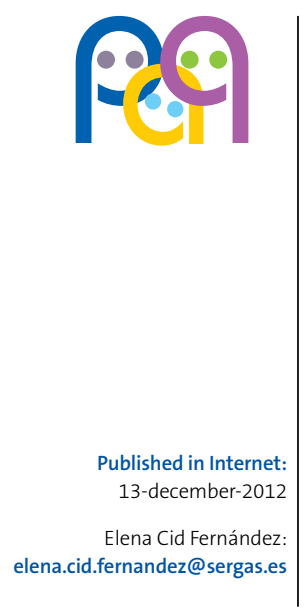

ublished in Internet:

Elena Cid Fernández elena.cid.fernandez@sergas.es

\section{Sociodemographic prevalence and factors that condition the use of jewellery (and the perceived risk of accidents involved in children less than two years old)}

\author{
E. Cid Fernández ${ }^{\mathrm{a}}$, P. Meseguer Yebrab ${ }^{b}$ S. Abad Rodríguez ${ }^{\mathrm{c}}$, \\ A. Hermida Prieto ${ }^{d}$, M. M. Guerra García ${ }^{e}$
}

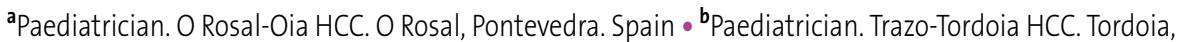
A Coruña. Spain • ${ }^{\mathcal{P}}$ Paediatrician. Arteixo-Meicende HCC. Meicende, A Coruña. Spain • dPaediatrician. Pontedeume HCC. Pontedeume, A Coruña. Spain • ePrimary care pharmacist. Porriño HCC.

Porriño, Pontevedra. Spain.

Objectives: to determine the prevalence of jewels use (and the perception of risk involved) in children under two years old and establish the sociodemographic and cultural factors that determine it.

Material and methods: we designed an observational descriptive transversal study. We conducted a questionnaire to parents in the pediatric outpatient clinics of 4 health areas during six months. The descriptive variables concerning infants were age, sex, number of siblings, order and cohabitants. Parents' variables were age, sex, educational level, occupation, country of origin, place of residence and religion. Relating to jewels: type, material, origin, use, time, subject and situation of use. We also asked about the associated risk of accidents perceived.

Results: there were 319 questionnaires. People that gave jewels to infants were more often first-degree relatives $(74.1 \%)$. The risks of potential injury attributed to its use emphasized strangulation by chains $(63.7 \%)$ and choking by rings (19.9\%). Forty percent of children, whose parents knew cases of jewels' accidents, used at least one. The older children had more jewels, although its use in the minors of 6 months predominated. The parents of the smallest and eldest children, within the studied rank of age, were those that perceived a major risk in the use of jewels.

Conclusions: jewel use among infants was very frequent. Their families did not show a clear perception of risk respecting to this habit and they had not either received the sufficient information to avoid it.
Key words:

- Jewels

- Infant

- Accidents

- Prevention

\title{
Prevalencia y factores sociodemográficos que condicionan el uso de joyas (y la percepción del riesgo de accidentes que conlleva) en niños menores de dos años
}

Objetivos: conocer la prevalencia del uso de joyas (y la percepción del riesgo que conlleva) en niños menores de dos años de edad y establecer los factores sociodemográficos y culturales que lo determinan.

Material y métodos: se diseñó un estudio observacional descriptivo transversal. Se realizó un cuestionario a padres en las consultas de Pediatría de cuatro áreas asistenciales durante seis meses. Las variables de caracterización referidas a los lactantes fueron: edad, sexo, número de hermanos, orden y convivientes. Las referidas a los padres: edad, sexo, nivel de estudios, profesión, país de origen, lugar de residencia y religión. Y las referidas a las joyas: tipo, material, procedencia, uso, tiempo, motivos y situaciones de uso. Así mismo, se preguntó sobre la percepción del riesgo de accidentes asociado.

Resultados: se contabilizaron 319 cuestionarios. Las personas que regalaron joyas a los lactantes fueron con mayor frecuencia los familiares en primer grado $(74,1 \%)$. Entre los riesgos de lesión potencial atribuidas a su uso, destacaron el estrangulamiento por cadenas $(63,7 \%)$ y el atragantamiento por anillos (19,9\%). El 40\% de los hijos cuyos padres conocían algún caso de accidente por joyas usaba al menos una. Tenían más joyas los niños de mayor edad, aunque predominaba su uso en los menores de seis meses. Los padres de los niños más pequeños y de los mayores, dentro del rango de edad estudia-

Palabras clave: - Joyas

- Lactante

- Accidentes

- Prevención do, eran los que percibían mayor riesgo en el uso de las joyas.

Conclusiones: el uso de joyas entre los lactantes fue muy frecuente. Sus familias no mostraron una clara percepción de riesgo respecto a este hábito y tampoco habían recibido la información suficiente como para evitarlo. 


\section{INTRODUCTION}

In most western countries, accidents constitute the leading cause of child mortality up to 15 years of age ${ }^{1}$. Throughout the year 2005, 841 children and adolescents died in Spain for this reason ${ }^{2}$. Accidents are a preventable healthcare issue, which is the reason why it may be more fitting to refer to them as injuries rather than accidents. The word accident implies events that happen by chance, that do not conform to a pattern, and are unpredictable. Since most of the injuries suffered by children occur in circumstances that are fairly predictable $^{3}$, we should all, as professionals involved in childcare and paediatric healthcare, make interventions to contribute to decreasing their incidence.

In the past few decades we have witnessed significant progress both in the knowledge of the risk factors for injuries, as well as in the design of more efficient and satisfactory programmes for their prevention and management ${ }^{4}$. Nevertheless, further action is needed to increase the awareness of the public in regard to the risks of injury for children and adolescents in the home, and to take greater effective preventative measures ${ }^{2}$.

It has been proven that involving the family and the community fosters safer behaviour ${ }^{5}$. The information must be adapted to the child's stage of development, and presented in a suitable manner in the form of prevention guidelines during the wellchild visit, although any other contact with the family unit, the school, or the social environment for other reasons should be used to reinforce this message $e^{6,7}$

Infants start to develop autonomy as they explore their environment, and frequently manipulate nearby objects and put them in their mouths, with choking being one of the leading causes of morbidity and mortality in the first three years of life ${ }^{8}$. The risk of accidents happening is particularly high in this stage of development, during which parents and caregivers should be particularly diligent with safety measures.

\section{MATERIAL AND METHODS}

We designed an observational descriptive crosssectional study. The study framework consisted of the Primary Care Paediatric office in six healthcare centres: Oia and O Rosal (Vigo healthcare district), Trazo and Tordoia (Santiago healthcare district), Meicende-Arteixo (A Coruña healthcare district) and Pontedeume (Ferrol healthcare district). We set an enrolment period of six months (from January to June 2011), since in this time span every child would have gone through at least one routine check-up. The study included all children of ages between zero and two years served by the Programa de Salud Infantil (Well-Child Programme). The study excluded those children whose guardians or persons accompanying them refused to participate in the study, and children who were institutionalised. In all cases, we requested a written informed consent from the participants. The questionnaires were processed anonymously.

We defined jewellery as any object fitting the definition of the Real Academia Española for the term: "Any object made of gold, silver or platinum worn for the purpose of adornment". Our study also included objects made of wood, plastic, or yarn. We excluded earrings because, while they may cause injuries, their use is so deeply rooted in the culture of our society that it would be very difficult to modify this behaviour.

As a measuring tool we designed a 53-question survey that would allow us to standardise the interview procedure and quantify the information. We recorded personal characteristic variables for the children (age in months, sex, number of siblings, sibling order among them, and the presence, number, and relationship to the child of additional household members-defined as those who live with the child and are not part of the basic family unit formed by the parents and children) and for the parents or accompanying adults (age, educational level, occupation, country of origin should it not be Spain, place of residence, and religious affiliation). We also recorded data about the source 
of the jewellery and what it was made of, whether it was worn or not and the reasons for it, how long the child had been wearing it and on which occasions, the perceived risk of its use, the availability of information on the hazards posed by jewellery, and the source of this information. For the dependent variable, we calculated the prevalence of jewellery use, defined as the proportion of children that wore jewellery during the period under study. The educational level of the parents was divided into five categories according to Law 14/1970, the General Education and Education Reform Funding Act. The occupation was categorised according to the Structure of the Standard Classification of Occupations, 2008. The place of residence was categorised as a function of population size into urban (settlements with populations greater than 30000), semi-urban (populations between 10000 and 30000) and rural settings (populations less than 10000).

The qualitative variables were expressed as absolute frequencies and percentages, and the quantitative variables as means with a $95 \%$ confidence interval (CI 95\%). The variables were compared using Pearson's correlation coefficient, considering the correlation statistically significant if $\chi^{2}<0.05$. We used the $\operatorname{SPSS}^{\oplus} 15.0$ software for the statistical analysis.

\section{RESULTS}

The study included 319 questionnaires corresponding to the same number of children, out of who 166 (52.0\%) were male, and 153 (48.0\%) female. The mean age was 11.0 months, with a $95 \% \mathrm{Cl}$ of 7.5-14.6. The age ranged between 1 and 21 months. Table 1 describes the sociodemographic characteristics of the surveyed individuals; Table 2 their educational level; and Table 3, the occupation of the parents. In every instance, the additional household members were first- and seconddegree relatives (grandparents, aunts, or uncles).

The characteristics pertaining to the ownership and use of jewellery are described in Table 4. In
197 cases (74.1\%), the jewellery was a gift from first-degree relatives (parents, grandparents, and godparents); in 49 (18.4\%), from second-degree relatives (uncles and aunts), and in 19 cases (7.1\%) the jewellery was given by other people. Among the risks attributed to the use of jewellery, the most frequent were the potential strangulation of the child with a necklace (63.7\%), and choking with a ring (19.9). Table 5 presents the risks attributed to each type of jewellery and the source of the information regarding that risk. We observed that for $40.0 \%$ of those who knew of at least one case of child injury caused by jewellery, the child used at least one piece of jewellery, and that such information had been given by people in the immediate environment or gained from personal experience in $88.9 \%$ of cases.

As for the relationship between jewellery ownership and the age of the child, we found that it was statistically significant $\left(\chi^{2}=0.014\right)$, with the likelihood of owning jewellery increasing with the age of the child. When we analysed the relationship with the number of additional household members, we observed that there was a higher rate of ownership in households with a lower number of additional members $\left(\chi^{2}=0.041\right)$. As for the environment, the rate of jewellery ownership was higher in rural settings than in urban settings $\left(\chi^{2}=0.007\right)$. Once we analysed the parental occupations, we observed that there was a higher rate of jewellery ownership among the children of self-employed professionals compared to the children of other professionals, although this difference did not reach statistical significance $\left(\chi^{2}=0.06\right)$. We did not find a relationship between jewellery ownership and the sex of the child, the age and educational level of the parents, the occupation of the mother, the number of children, and the sibling order of the child, immigration status, or religious affiliation.

When it came to the use of jewellery, we did find a correlation between the age of the child and the use of at least one piece of jewellery $\left(\chi^{2}=0.002\right)$, which was greater at younger ages (less than six months). When we analysed the relationship with the num- 


\begin{tabular}{|c|c|c|c|}
\hline & & No. (\%) & Mean $(95 \% \mathrm{Cl})$ \\
\hline \multirow[t]{3}{*}{ Person interviewed } & Father/mother & $311(97.50)$ & \\
\hline & Grandparents & $7(2.25)$ & \\
\hline & Other & $1(0.30)$ & \\
\hline \multirow[t]{2}{*}{ Age } & Father & & 34.95 (31.68 a 38.21$)$ \\
\hline & Mother & & 31.68 (29.21 a 34.16$)$ \\
\hline \multirow[t]{4}{*}{ Number of siblings } & One & $190(59.56)$ & \\
\hline & Two & $111(34.79)$ & \\
\hline & Three & $16(5.01)$ & \\
\hline & More than three & $2(0.62)$ & \\
\hline \multirow[t]{4}{*}{ Sibling order of child } & First & 195 (61.1) & \\
\hline & Second & $107(33.5)$ & \\
\hline & Third & $15(4.7)$ & \\
\hline & Fourth or more & $2(0.6)$ & \\
\hline \multirow[t]{2}{*}{ Additional household members } & Yes & $90(28.21)$ & \\
\hline & No & $229(71.78)$ & \\
\hline \multirow{4}{*}{$\begin{array}{l}\text { Number of additional household } \\
\text { members }\end{array}$} & One & $25(7.8)$ & \\
\hline & Two & $45(14.1)$ & \\
\hline & Three & $10(3.1)$ & \\
\hline & Four or more & $10(3.1)$ & \\
\hline \multirow[t]{3}{*}{ Setting of the home } & Rural & $243(76.2)$ & \\
\hline & Urban & $76(23.8)$ & \\
\hline & Semi-urban & 0 & \\
\hline \multirow[t]{2}{*}{ Immigration status } & Yes & $21(6.60)$ & \\
\hline & No & $298(93.40)$ & \\
\hline \multirow[t]{4}{*}{ Country of origin } & South America & $7(2.19)$ & \\
\hline & Europe & $2(0.63)$ & \\
\hline & Asia & $1(0.31)$ & \\
\hline & Africa & $1(0.31)$ & \\
\hline \multirow[t]{4}{*}{ Religious affiliation } & Catholic & $313(98.10)$ & \\
\hline & Muslim & $1(0.30)$ & \\
\hline & Agnostic & $3(0.90)$ & \\
\hline & Other & $2(0.60)$ & \\
\hline
\end{tabular}

IC 95\%: 95\% confidence interval.

ber of additional household members, the probability of wearing jewellery increased as the household decreased in size $\left(\chi^{2}=0.013\right)$. If the family lived in a rural setting, the probability of wearing jewellery was greater $\left(\chi^{2}=0.004\right)$ than in an urban setting. We did not find a relationship between jewellery use and the sex of the child, the age, the education, and the occupation of the parents, the number of siblings and the sibling order of the child, immigrant status, and religious affiliation.

The use of jewellery and the availability of information were related to risk perception $\left(\chi^{2}=0.000\right.$ and $\chi^{2}=0.009$, respectively). The parents of the youngest and oldest children perceived risk more $\left(\chi^{2}=0.048\right)$. When it comes to risk perception and the age of the adults, risk perception among mothers was higher in the age group ranging from 28 to 32 years $\left(\chi^{2}=0.011\right)$. We observed the same trend among the fathers, although the age range was slightly higher, and did not reach statistical significance $\left(\chi^{2}=0.066\right)$. Risk perception was greater in households with fewer members $\left(\chi^{2}=0.013\right)$. We did not find any differences depending on the setting of the home. 
Table 2. Educational level according to Law 14/1970 on General Education and Education Reform Funding

\begin{tabular}{|l|c|c|}
\multirow{2}{*}{\multicolumn{1}{|c|}{ Educational Level }} & \multicolumn{2}{c|}{ No. (\%) } \\
\cline { 2 - 3 } & Father & Mother \\
\hline No education & $1(0.3)$ & $4(1.3)$ \\
\hline Primary education & $174(54.5)$ & $166(52.0)$ \\
\hline Vocational training & $92(28.8)$ & $82(25.7)$ \\
\hline Secondary education & $24(7.5)$ & $27(8.5)$ \\
\hline College degree & $24(7.5)$ & $40(12.5)$ \\
\hline
\end{tabular}

\section{DISCUSSION}

Accidents constitute the main cause of death for children in industrialised countries, and also involve a significant associated morbidity. In a report made to assess progress in child safety, developed by the initiative of the European Union initiative and published in 2009, the data on Spain showed that reasonable effort has been done in some areas such as child and adolescent passenger safety, motorised two-wheeler safety, and poisoning prevention. However, this same document highlights the fact that more could be done to prevent injuries that happen in the home and its surroundings, due to falls, burns, suffocation, choking, or strangulation ${ }^{2}$. We believe that in this regard, and within the category of domestic accidents, jewellery should be an issue to consider toward the improvement of child safety, since the data obtained in this study show its generalised use at very early ages and the potential risk of accidents associated to this behaviour. More specifically, $84 \%$ of the children in the study owned jewellery, with the majority owning more than one piece, and with half of them wearing jewellery regularly. We ought to note that few publications include the recommendation of not using these objects in children this young ${ }^{9-11}$

In the current study we observed that the older the children were, the more pieces of jewellery they owned. However, jewellery was worn more often by the younger children. A particularly relevant finding was that one fourth of the children had already started wearing jewellery by the 15th day from birth, and when we analysed the period ranging from birth to age three months, this figure rose to $64 \%$. The precocious use of jewellery could be accounted for by the fact that these objects were given as presents very early, when the child was born or baptised, and most children started to use them at that point. This is an observation that must be taken into consideration, since among the risk factors for injuries, when it comes to the place and frequency with which they happen, age has a strong influence because it is associated to particular developmental abilities and anatomical characteristics ${ }^{12,13}$. Furthermore, most children wore the jewellery daily and 24

Table 3. Occupation according to the Structure of the International Standard Classification of Occupations, 2008 (ISCO-08)

\begin{tabular}{|l|c|c|}
\hline \multicolumn{1}{|c|}{ Occupation } & \multicolumn{2}{c|}{ No. (\%) } \\
\cline { 2 - 3 } & Father & Mother \\
\hline Managers & $11(3.4)$ & $2(0.6)$ \\
\hline Professionals & $10(3.1)$ & $18(5.6)$ \\
\hline Technicians and associate professionals & $12(3.8)$ & $13(4.1)$ \\
\hline Clerical support workers & $10(3.1)$ & $33(10.3)$ \\
\hline Service and sales workers & $35(11.0)$ & $73(26.9)$ \\
\hline Skilled agricultural, forestry and fishery workers & $7(2.2)$ & $6(1.9)$ \\
\hline Craft and related trades workers & $179(56.1)$ & $43(13.5)$ \\
\hline Plant and machine operators and assemblers & $42(13.2)$ & $8(1.3)$ \\
\hline Elementary occupations & $2(0.6)$ & $103(32.3)$ \\
\hline Armed forces occupations & $1(0.3)$ & 0 \\
\hline Retired & $1(0.3)$ & 0 \\
\hline Unemployed & $6(1.9)$ & $21(6.6)$ \\
\hline Other & $1(0.3)$ & $3(0.9)$ \\
\hline Does not know/Does not answer & $2(0 \circ 6)$ & 0 \\
\hline
\end{tabular}




\begin{tabular}{|c|c|c|c|c|}
\hline \multicolumn{3}{|c|}{ Own jewellery } & \multirow{2}{*}{$\begin{array}{c}\text { No. (\%) } \\
267(83.7)\end{array}$} & \multirow[t]{2}{*}{ Mean $(95 \% \mathrm{Cl})$} \\
\hline \multirow[t]{11}{*}{ Yes } & Total & & & \\
\hline & \multirow[t]{4}{*}{ Reason } & Gift & $132(49.4)$ & \\
\hline & & Identifying object & $110(41.2)$ & \\
\hline & & Religious & $16(6.0)$ & \\
\hline & & Other & $9(3.4)$ & \\
\hline & \multirow[t]{3}{*}{ Type of jewellery } & Bracelet & $243(91.0)$ & \\
\hline & & Chain necklace & $191(71.5)$ & \\
\hline & & Ring & $54(20.2)$ & \\
\hline & \multirow[t]{3}{*}{ Material } & Gold & $261(98.1)$ & \\
\hline & & Silver & $3(1.1)$ & \\
\hline & & Other & $2(0.7)$ & \\
\hline \multirow[t]{5}{*}{ No } & Total & & $52(16.3)$ & \\
\hline & \multirow[t]{4}{*}{ Reason } & Does not like them & $16(30.8)$ & \\
\hline & & Were not received as a gift & $22(42.3)$ & \\
\hline & & Fear & $9(17.3)$ & \\
\hline & & Other & $5(9.6)$ & \\
\hline \multicolumn{5}{|c|}{ Wear jewellery } \\
\hline \multicolumn{2}{|l|}{ Yes } & & $141(52.8)$ & \\
\hline \multirow{3}{*}{\multicolumn{2}{|c|}{ Type of jewellery }} & Bracelet & $135(55.6)$ & \\
\hline & & Chain necklace & $32(16.8)$ & \\
\hline & & Ring & $3(5.6)$ & \\
\hline \multicolumn{3}{|c|}{ Age at start of use (in months) } & & $3.38[2.7-4.0]$ \\
\hline \multirow{5}{*}{\multicolumn{2}{|c|}{ Times worn }} & Daily & $131(92.9)$ & \\
\hline & & Holidays & $5(3.5)$ & \\
\hline & & Family gatherings & $4(2.8)$ & \\
\hline & & Other occasions & $1(0.7)$ & \\
\hline & & Does not know/does not answer & $2(1.4)$ & \\
\hline \multirow{5}{*}{\multicolumn{2}{|c|}{ Take them off at some point }} & Never & $128(90.8)$ & \\
\hline & & During sleep & $7(5.0)$ & \\
\hline & & During play & 0 & \\
\hline & & Sometimes & $5(3.5)$ & \\
\hline & & Does not know/does not answer & $1(0.7)$ & \\
\hline
\end{tabular}

IC 95\%:95\% confidence interval.

hours a day, which increases the risk of injury, as there is a greater time of exposure. In this sense, we should not forget that a critical factor in asphyxia injuries is the child's access to the product in an unsupervised environment ${ }^{14}$. As age increased the use of jewellery was lower, not because it was taken from the child, but perhaps because it had broken or no longer fitted. On the other hand, the smaller the family unit, the more frequent it was for children to own and wear jewellery. This could be related to the lower availability of economic resources in households with more family members.
In urban settings, jewellery ownership and the perceived risk of their use were both higher. Jewellery ownership may be associated to a higher purchasing power and higher demand. And risk perception to a higher level of education and to access to the latter. The lower risk perception in rural settings, as opposed to urban ones, may account for why jewellery use is more prevalent in such areas. This could be compounded by cohabiting with the grandparents, a factor that favours jewellery use, since they are the people that most often give the jewellery as presents. The perceived risk is greater among the parents of the youngest infants and of 


\begin{tabular}{|c|c|c|}
\hline & & No. (\%) \\
\hline \multicolumn{3}{|c|}{ Perception of the risk } \\
\hline \multicolumn{2}{|l|}{ Yes } & $267(83.7)$ \\
\hline \multirow[t]{3}{*}{ Most dangerous item } & Bracelet & $3(1.1)$ \\
\hline & Chain necklace & $200(74.9)$ \\
\hline & Ring & $64(24.0)$ \\
\hline \multicolumn{2}{|c|}{ Were informed about the risk } & $68(21.3)$ \\
\hline \multirow[t]{6}{*}{ Source of information about the risk } & Healthcare staff & $18(26.5)$ \\
\hline & Friends and family members & $31(45.6)$ \\
\hline & Mass media & $9(13.2)$ \\
\hline & School/child-care centre & $2(2.9)$ \\
\hline & Other sources & $4(5.9)$ \\
\hline & Does not know/Does not answer & $4(5.9)$ \\
\hline
\end{tabular}

the oldest children (at both extremes of the age range we analysed). The lack of autonomy perceived in the youngest children, and the drive to explore, the lack of fear, and the mobility and manipulation skills that characterise the older ones may be the factors why parents perceive these children as more likely to get injured ${ }^{15}$. However, this seems to be in contradiction with the fact that it is precisely the youngest children that wore jewellery the most, and the older ones that owned it most frequently, facts that seem hard to explain. It also seems paradoxical that the risk is perceived the most in smaller households, even though it is in these small family units that children own and wear jewellery the most.

In $84 \%$ of the cases, parents thought that jewellery posed hazards. Still, over a third of those who reported this also reported that their children used jewellery. Furthermore, $40 \%$ of the parents interviewed had heard of injuries caused by jewellery, even among their own relatives, and still had their children wear it. This seems to suggest that this practise is not truly seen as a potential cause of injury.

It is a well-established fact that the prevention of childhood injuries rests on three pillars: research (epidemiology studies), legislation (technical safety guidelines), and education (preventative education efforts) carried out in an ongoing manner and at different levels ${ }^{12}$. In this regard, we must high- light the fact that over $90 \%$ of those interviewed reported that they had not received any information about this risk from healthcare professionals. In the few cases that the families had been given information about the potential risk of this practise outside of the healthcare environment, family and friends were the most common source. This should make us wonder whether we should adapt the content of our prevention efforts to include this matter to modify the general perception on the subject in areas where jewellery use is a widespread custom. Keeping in mind that a substantial percentage of infants are already wearing jewellery by the 15th day of life, perhaps the midwife, the paediatrician, and the nursing staff should inform during prenatal visits of the unsuitability and the potential danger of giving these objects to babies. And advise that if such gifts were received, they should at least not be worn during these early years of life. Paediatricians and other Primary Care health workers, as well as early childhood education workers, should be encouraged to counsel parents on injury prevention, overcoming whatever barriers may be preventing this practise, and incorporating it into their routine work ${ }^{16-18}$.

In short, in the current study we observed that the profile of the child who has jewellery is that of an infant in an urban setting, with few additional members in the household, and parents who were 
self-employed from an occupational standpoint. On the other hand, the profile of the child who wears jewellery is that of an infant younger than six months who belongs to a small household and lives in a rural setting. There was a greater perception of the risk involved in the use of jewellery among parents 25 to 35 years of age who lived in an urban setting and in households with few or no additional members, although overall we could state that there was a low perceived risk for the practise that we were analysing.

Consequently, taking into account the magnitude of the problem and the potential for serious injuries it poses, as well as how easy it would be for professionals to intervene, we believe that proactive action should be taken in any population where it is customary for infants to wear jewellery. And this should be done keeping in mind that certain social factors, such as the degree of maturity, experience, and information of the parents, and/ or the size of the household, may influence the ability of parents to supervise their children. Thus, the recommendation to avoid the use of jewellery should be included in the anticipatory guidelines

\section{BIBLIOGRAPHY}

1. Casaní Martinez C. Accidentes en la infancia: su prevención, tarea de todos. Rev Pediatr Aten Primaria. 2004;6:583-95.

2. Mackay M, Vincenten J. Child Safety Report Card 2009-Spain. Amsterdam: European Child Safety Alliance, Eurosafe; 2009 [en línea] [consultado el 11/01/de 2011]. Disponible en www.msps.es/en/ profesionales/saludPublica/prevPromocion/Lesio nes/docs/InformeSegInfantil_2009.pdf

3. Rivara FP, Grossman D. Control de lesiones. En: Behrman RE, Kliegman RM, Jenson HB (eds.). Nelson Tratado de Pediatria, 17. a ed. Madrid: Elsevier España; 2006. p. 256-63.

4. Christakis DA, Zimmerman FJ, Rivara FP, Ebel B. Improving Pediatric Prevention via the Internet: A Randomized, Controlled Trial. Pediatrics. 2006;118:1157-66. for accidental injuries and the information provided to families during scheduled visits and wellchild visits, as well as in visits that occur for any other reason.

\section{CONCLUSIONS}

- Our results reflected that, at least in the area that we studied, the use of jewellery at early ages was very frequent, even among newborns.

- There was no clear perception of the risk involved in the use of jewellery among parents or caregivers, nor in the overall population.

- In general, families reported that they had not been given information about the disadvisability of this practise.

\section{CONFLICT OF INTERESTS}

The authors declare that they had no conflict of interests when it came to preparing and publishing this paper.

\section{ACRONYMS}

IC 95\%: 95\% confidence interval.
5. Quinlan KP, Sacks JJ, Kresnow M. Exposure and compliance with pediatric injury prevention counselingUnited States,1994. Pediatrics. 1998;102:e55.

6. Gardner HG; Committe on injury, violence and poison prevention. Office-based counseling for unintentional injury prevention. Pediatrics. 2007;119:202-6.

7. Di Giuseppi C, Roberts IG. Individual-level injury prevention strategies in the clinical setting. Future Child. 2000;10:53-82

8. Committe on Injury, Violence, and Poison Prevention. Prevention of choking among children. Pediatrics. 2010;125:601-7.

9. Esparza MJ; Grupo PrevInfad/PAPPS Infancia y Adolescencia. Prevención de accidentes en el hogar para casas con niños de 1 a 4 años. Asociación Española de Pediatría de Atención Primaria: Famiped [en línea] [consultado el 22/10/2012]. Disponible en http:// famiped.es/en/volumen-3-no-4-diciembre-2010 
10. Del Pozo Rodríguez V, Miñana Novell E. Cómo hacer prevención de los accidentes infantiles desde la consulta. FMC. 2011;18(2):73-7.

11. Aguilar Peral M. Prevención de accidentes en la infancia Consejos dirigidos a los padres. Sociedad de Pediatría de Atención Primaria de Extremadura [en línea] [consultado el 22/10/2012]. Disponible en www.spapex.es/pdf/prevaccid.htm

12. Esparza MJ;Grupo PrevInfad/PAPPS Infancia y Adolescencia. Prevención de accidentes en el hogar para casas con bebés de hasta 12 meses. Asociación Española de Pediatría de Atención Primaria: Famiped [en línea] [consultado el 22/10/2012]. Disponible en www.famiped.es/volumen-3-no-3-septiembre-2010

13. Mateu Sánchez J. Accidentes e intoxicaciones infantiles (medidas preventivas). Pediatr Integral. 2001;6: 55-72.
14. Nakamura SW, Pollack-Nelson C, Chidekel AS. Suction-Type Suffocation Incidents in Infants and Toddlers. Pediatrics. 2003;111:e12-e16.

15. Esparza Olcina MJ; Grupo PrevInfad/PAPPS Infancia y Adolescencia. Prevención de lesiones infantiles por accidentes. Rev Pediatr Aten Primaria. 2009;11:65766.

16. Cohen LR, Runyan CW. Barriers to pediatric injury prevention counselling. Inj Prev. 1999;5:36-40.

17. Schuster MA, Duan N, Regalado M, Klein DJ. Anticipatory Guidance. What Information Do Parents Receive? What Information Do They Want? Arch Pediatr Adolesc Med. 2000;154;1191-8.

18. Casaní Martínez C, Morales Suárez-Varela M. Accidentes en la infancia. Resultados del Servicio de Urgencias del Hospital La Fe. Rev Pediatr Aten Primaria. 2002;14:209-22. 